\title{
DISTINCTIVE SIRE1 RETROTRANSPOSON PATTERNS ON BARLEY CHROMOSOMES?
}

\author{
Elif KARLIK $^{1^{*}}$, Nermin GÖZÜKIRMIZI ${ }^{2}$ \\ ${ }^{1}$ İstinye University, Department of Molecular Biology and Genetics, İstanbul, TURKEY \\ 2 İstanbul University, Faculty of Sciences, Department of Molecular Biology and Genetics, İstanbul, TURKEY
}

Cite this article as:

Karlık E., Gözükırmızı N. 2021. Distinctive SIRE1 Retrotransposon Patterns on Barley Chromosomes? Trakya Univ J Nat Sci, 22(1): 9-15, DOI: 10.23902/trkjnat.773302

Received: 24 July 2020, Accepted: 09 October 2020, Online First: 07 November 2020, Published: 15 April 2021

Edited by:

Ylld $z$ Aydin

*Corresponding Author: Elif Karllk

elif.karlik@istinye.edu.tr

\section{ORCID ID:}

orcid.org/0000-0003-0669-2725

Key words:

Fluorescence in situ hybridization

Retrotransposon

SIRE1

Barley

$E N V$

$G A G$
Abstract: SIRE1 is an active and relatively high copy-number retroelement belongs to the Tyl/Copia long terminal repeat (LTR) retrotransposon superfamily. Distinctive SIRE1 elements ( $E N V$ and $G A G$ ) distributions in barley genome were observed by using fluorescent in situ hybridization (FISH). We performed PCR to obtain tetramethylrhodamine-dUTP (TRITC)-labelled probes. Localizations of SIRE1 ENV and GAG domains were demonstrated under confocal microscope on Hordeum vulgare L. cv. Hasat root preparations. Our results revealed the distributions of SIRE1 elements $E N V$ and $G A G$ in barley genome. These results may provide to uncover the organization of SIRE retrotransposon pattern in barley genome.

Özet: SIRE1, Tyl/Copia Uzun Uç Tekrarlı (Long Terminal Repeats- LTR) retrotranspozon üst ailesine ait olan aktif, nispeten yüksek kopyalı bir retroementtir. Arpa genomundaki ayırt edici SIRE1 elementlerinin ( $E N V$ ve $G A G$ ) dağılımları floresan in situ hibridizasyonu (FISH) kullanılarak gözlemlendi. Tetramethylrhodamine-dUTP (TRITC)-işaretli probların elde edilmesinde PCR gerçekleştirildi. SIRE1 ENV ve GAG domainlerinin yerleşimleri, Hordeum vulgare L. cv. Hasat kök preparatlarında konfokal mikroskobu altında gösterildi. Sonuçlarımız, arpa genomundaki SIRE1 elementlerinin $E N V$ ve $G A G$ dağılımlarını göstermektedir. Bu sonuçlar, SIRE1 elementlerinin arpa genomunun organizasyonunun ortaya çıkarılmasına katkı sağlayacaktır.

\section{Introduction}

Transposable elements (TEs) are mobile genetic elements and are distributed throughout the plant genome, over the $14 \%$ of Arabidopsis thaliana (L.) Heynh. genome, over the $80 \%$ maize genome and $80.8 \%$ of barley genome consist of TEs (AGI 2000, Schnable et al. 2009, Mascher et al. 2017). TEs constitute DNA fragments which can move through the genome using a DNA intermediate (DNA transposons) or an RNA intermediate (retrotransposons). Retrotransposons encode their own proteins for replication and integration back into the genome can be subdivided into two main subclasses as LTR retrotransposons and non-LTR retrotransposons. Although both LTR and non-LTR retrotransposons are located on plant genomes, LTR retrotransposons are more abundant than non-LTR retrotransposons (Voytas \& Boeke 2002, Sandmeyer et al. 2002, Schulman \& Wicker 2013) and are divided into two main superfamilies known as Tyl/copia and Ty3/gypsy groups (Wicker et al. 2007).

Tyl/copia (Pseudoviridae) elements are prevalent in plants and grouped into three genera: Pseudovirus (Tyl), Hemivirus (Copia) and the Sirevirus which are closely related to the retroviruses, but have a different polyprotein (pol) gene order (Kumar \& Bennetzen 1999, Llorens et al. 2009). Sireviruses are plant specific unique retrotransposons among Tyl/copia elements (Gao et al. 2003, Bousios et al. 2010). Sequence studies revealed that highly conserved sequence motifs of Sireviruses have been found within the extremely divergent non-coding part of the genome (Bousios et al. 2010). Recently, Sireviruses are named after the SIRE1 element from soybean, and they were originally named as Agroviruses according to their host specificity that they were only colonized in plants (Peterson-Burch \& Voytas 2002). Two notable features of Sireviruses can be considered as that they consist of an env-like gene after pol and encode a significantly larger $\mathrm{Gag}$ protein which differentiate them from other Tyl/copia genera (Peterson-Burch \& Voytas 2002, Havecker et al. 2005). However, no known functions for either of these additional coding regions have been identified (Bousios et al. 2010).

Interestingly, some evidence indicated that individual retrotransposon families demonstrate typical patterns of chromosomal localizations (Presting et al. 1998, Friesen et al. 2001). However, with the completion of the DNA 
sequencing project of Arabidopsis thaliana genome and various plant species, including barley, with large genome allowed the analysis of the retroelement distribution, and these studies revealed that TEs demonstrated non-random distribution through chromosomes (AGI 2000, Mascher et al. 2017). In barley genome project, Mascher et al. (2017) revealed that $3.7 \mathrm{~Gb}(80.8 \%)$ of barley genome consists of transposable elements and that only $10 \%$ of them are intact and potentially active. They distinguished the seven barley chromosomes into three fractions as fractions 1,2 and 3 . In the proximal fraction 3 -where older transposable elements are diverged, unique and predominated- contains mostly repetitive 20-mers. Moreover, fraction 3 is favoured by Gypsy retrotransposons, while fractions 1 and 2 are populated by Copia elements. These differences in the relative abundance of retrotransposon families are considered as distinct distributions of functional domains. Additionally, Mariner transposons preferentially occupy within $1 \mathrm{~kb}$ up- or downstream of the coding regions of genes. However, Harbinger and long interspersed elements are observed to be located further away from genes. Selective pressures are considered to underlie the distribution of different types of transposable elements around genes. As expected, the smallest transposable elements such as Mariner may be more tolerated in regions close to the genes. However, intriguingly, the Harbinger superfamily elements possess a clear preference for promoter regions, while long interspersed elements preferentially possess for downstream regions of genes. Moreover, the large transposable elements such as LTR retrotransposons and CACTA elements are located at greater distances from genes (Mascher et al. 2017).

Fluorescence in situ hybridization (FISH) using target-specific DNA probes have become a routine technique in modern molecular biology, cell research and medical diagnosis (Hausmann \& Cremer 2003). However, application of FISH has been shown to be more difficult, because of the cell wall, the cytoplasm, which prevents chromosome spreading, low metaphase indices and often similar chromosome morphology (Salvo-Garrido et al. 2001). The distribution of retrotransposon families has been analysed in a variety of plant genomes including, Allium cepa, Aegilops speltoides, Brachypodium distachyon and Glycine max using FISH (Lin et al. 2005, Kiseleva et al. 2014, Shams and Olga Raskina 2018, Li et al. 2018). Li et al. (2018) performed FISH analysis on pachytene chromosomes of soybean BAC and three subclones. FISH analysis revealed that a recently inserted SIRE1, a solo SIRE1 LTR and fragments of Calypso-like retroelements were located within this BAC. In barley, Acevedo-Garcia et al. (2013) used FISH analysis and YAC library to isolate Rorl gene, which encodes Required for mlo-specified resistance genes and important for basal defence, due to fine mapping and gene synteny strategies. Additionally, BAC clones have also been used to demonstrate BARE1 patterns on barley chromosomes by FISH (Vicient et al. 1999).
The aim of this study was to present the localization of SIRE1 patterns in Hordeum vulgare L. chromosomes using labelled-PCR products via FISH. SIRE1 patterns were observed under confocal microscope on barley root preparations. Our results indicated the SIRE1 localizations in barley genome.

\section{Materials and Methods}

\section{Plant materials}

Hordeum vulgare L.cv. Hasat was provided from the Directorate of Trakya Agricultural Research Institute. The plants were grown in a growth chamber under $16 \mathrm{~h}$ light $/ 8$ $\mathrm{h}$ dark and $25^{\circ} \mathrm{C} \pm 2{ }^{\circ} \mathrm{C}$ conditions. Relative humidity was kept at $60-75 \%$. After 72 hours, plants were harvested, directly treated with liquid nitrogen and then stored at $80^{\circ} \mathrm{C}$ until DNA extraction.

\section{gDNA Extraction}

gDNA were extracted from $200 \mathrm{mg}$ of the samples by using a modified version of the cetyltrimethylammonium bromide (CTAB) precipitation method described in Mafra et al. (2008). Specifically, $200 \mathrm{mg}$ homogenized sample was incubated with $1 \mathrm{ml}$ Edward's buffer $(0.5 \%$ (w/v) SDS, $250 \mathrm{mM} \mathrm{NaCl}, 25 \mathrm{mM}$ EDTA, $200 \mathrm{mM}$ Tris pH 8.0) at $95^{\circ} \mathrm{C}$ for $5 \mathrm{~min}$ (Cold Spring Harbor Laboratory, 2005). The mixture was centrifugated at $16,000 \mathrm{~g}$ for $15 \mathrm{~min}$. afterwards, the supernatant was extracted twice with chloroform. The aqueous phase was incubated with 2 volumes of CTAB precipitation solution, then the CTAB protocol was followed as previously described (Mafra $e t$ al. 2008). DNA yield and purity were measured by UV spectrophotometry at 230, 260 \& $280 \mathrm{~nm}$ using a NanoDrop 2000c instrument (Thermo Scientific, Wilmington, DE, USA). DNA integrity was evaluated by agarose gel electrophoresis with which samples were separated on $1 \%$ agarose gels in $1 \mathrm{X}$ TAE buffer.

\section{Chromosome preparation for FISH analysis}

Seeds were placed randomly in Petri dishes containing filter paper soaked in only water to germinate in an incubator at $18-25^{\circ} \mathrm{C}$ in the dark for 3 days. Root tips were harvested, directly fixed in Carnoy fixative (3:1 ethanol:acetic acid solution) without any chemical pretreatment and stored at $4^{\circ} \mathrm{C}$. Chromosome preparations and FISH analysis were performed according to Jenkins \& Hasterok $(2001,2007)$ with modifications. The slides were checked under the light microscope (Olympus UTVO.5XC-3) and kept in a freezer at $-20^{\circ} \mathrm{C}$.

\section{Development of probes and labelling}

The FISH probes used in this study were generated from two sets of data which are the ENV (envelope-like) and $G A G$ (encoding a structural protein) genes of SIRE1. To investigate the distribution of SIRE1, we amplified $E N V$ and $G A G$ domains of SIRE1 using designed specific primer sets (Table 1). The probes for $E N V$ and $G A G$ domains were designated by using IDT's PrimerQuest ${ }^{\mathscr{O}}$ Tool (2012). GC\% and Tm values of the probes were around 62 and between $47^{\circ}$ and $55^{\circ} \mathrm{C}$, respectively. The 
sequences of SIRE1 ENV and GAG were obtained from barley (KP420209 for GAG and KP420210 for ENV).

Probe synthesis was carried out individually by using SIRE1 ENV and GAG primers. The reactions were performed in a total volume of $50 \mu$ including $18.25 \mu \mathrm{l}$ nuclease-free $\mathrm{dH}_{2} \mathrm{O}, 25 \mu \mathrm{l}$ of HotStart PCR Master Mix (Bio-Rad), $1.5 \mu \mathrm{l}$ of each primer $(10 \mu \mathrm{M} / \mu \mathrm{l}), 1.75 \mu \mathrm{l}$ of tetramethylrhodamine-dUTP (TRITC) $(1 \mathrm{mM})$, and $2 \mu \mathrm{l}$ template DNA $(40 \mathrm{ng} / \mu \mathrm{l})$. PCR conditions were as follows: $94^{\circ} \mathrm{C}$ for $5 \mathrm{~min}$ followed by 40 cycles of $94^{\circ} \mathrm{C}$ for $25 \mathrm{~s}$, annealing $50^{\circ} \mathrm{C}$ for $25 \mathrm{~s}$ and $72^{\circ} \mathrm{C}$ for $30 \mathrm{~s}$. The reaction was completed by a final extension step at $72^{\circ} \mathrm{C}$ for $5 \mathrm{~min}$.

Table 1. Primers used in this study.

\begin{tabular}{ccc}
\hline \hline No & Primer Name & Sequence $\left(\mathbf{5}^{\prime} \rightarrow \mathbf{3}\right.$ ') \\
\hline \hline $\mathbf{1}$ & SIRE1 ENV $F$ & CGACAACACCAGAGGAGAATG \\
$\mathbf{2}$ & SIRE1 ENV $R$ & CGCCTTGGTGGCCAATTA \\
$\mathbf{3}$ & SIRE1 GAG $F$ & AACCGAGATGGAGGTAGTACA \\
$\mathbf{4}$ & SIRE1 GAG $R$ & GAAACGGCACACGCTAGA \\
\hline \hline
\end{tabular}

\section{Fluorescence in situ hybridization (FISH) analysis}

The FISH analysis protocol was adopted from Jenkins and Hasterok $(2001,2007)$ protocol with modifications. Chromosome spreads were scanned under light microscope with $\times 40$ objective to determine the number and quality of well-spread metaphase plates, and then they were treated with $100 \mu \mathrm{g} / \mathrm{ml}$ of RNase at $37^{\circ} \mathrm{C}$ for $1 \mathrm{~h}$. The hybridization mixture contains $20 \mu \mathrm{l}$ of deionised formamide $(50 \%), 8 \mu \mathrm{l}$ of dextran sulphate $(10 \%), 4 \mu \mathrm{l}$ of $20 \mathrm{X}$ SSC (2X SSC), $2 \mu \mathrm{l}$ of $10 \%$ SDS $(0.5 \%), 10 \mu \mathrm{l}$ of probe (75-200ng/slide), $1 \mu$ l of blocking DNA (sonicated salmon sperm DNA) (25-100X probe) and added sterile $\mathrm{dH}_{2} \mathrm{O}$ to bring final volume $40 \mu \mathrm{l}$. Final concentrations were indicated in parenthesis. The mixture was denatured at $85^{\circ} \mathrm{C}$ for $10 \mathrm{~min}$ and kept on ice for $10 \mathrm{~min}$. A $38 \mu \mathrm{l}$ aliquot of the hybridization mixture was applied onto each slide, covered with a coverslip and sealed with paper bond. Both chromosomal DNA and probe DNA on the slides were denatured together in a thermal cycler at $70^{\circ} \mathrm{C}$ for $6 \mathrm{~min}$ and hybridized with each other at $37^{\circ} \mathrm{C}$ overnight in a humid dark box. Afterwards, hybridized the chromosome spreads were washed three times in 2X SSC: once $2 \mathrm{X}$ SSC to float coverslips off, once in $15 \%$ formamide/0.1X SSC and again once in $15 \%$ formamide/ $0.1 \mathrm{X} \mathrm{SSC}$, each for $10 \mathrm{~min}$ at $42^{\circ} \mathrm{C}$. Then, the slides were washed in $2 \mathrm{X} \mathrm{SSC}$ for $3 \mathrm{~min}$ at $42^{\circ} \mathrm{C}$. This step was repeated twice with fresh $2 \mathrm{X} \mathrm{SSC}$ at $42^{\circ} \mathrm{C}$. Ultimately, the slides were washed three times in $2 \mathrm{X}$ SSC for $3 \mathrm{~min}$ at RT. Then, the slides were dehydrated in alcohol series (70, 90 and $100 \%$ ), each for $1 \mathrm{~min}$ at RT and waited in the dark for 15-20 min. Vectashield-DAPI mounting-staining medium $(7-10 \mu \mathrm{L})$ was dropped onto the chromosome spreads, which were then stored at $4{ }^{\circ} \mathrm{C}$ until used.

\section{Image acquisition}

To image the slides, 551-575 $\mathrm{nm}$ wavelengths for probes labelled with TRITC and 420-480 nm wavelengths for DAPI were used for fluorescence detection in the Leica DM5500 confocal microscope. The different fluorescent images were acquired separately. Afterwards, they were merged into single composite images. The signal images were analysed by Adobe Photoshop CC 2014.

\section{Results}

To characterize the abundance and localization patterns of soybean SIRE1 ENV and GAG domains in barley, we used root tip cells and SIRE1 ENV and GAG probes were labelled with TRITC. Specifically, we observed TRITC labelled SIREI ENV exhibited characteristic patterns at prophase in nucleus (Fig. 1). TRITC labelled SIRE1 GAG probes also demonstrated distinctive patterns in prophase phase in barley chromosomes (Fig. 2).

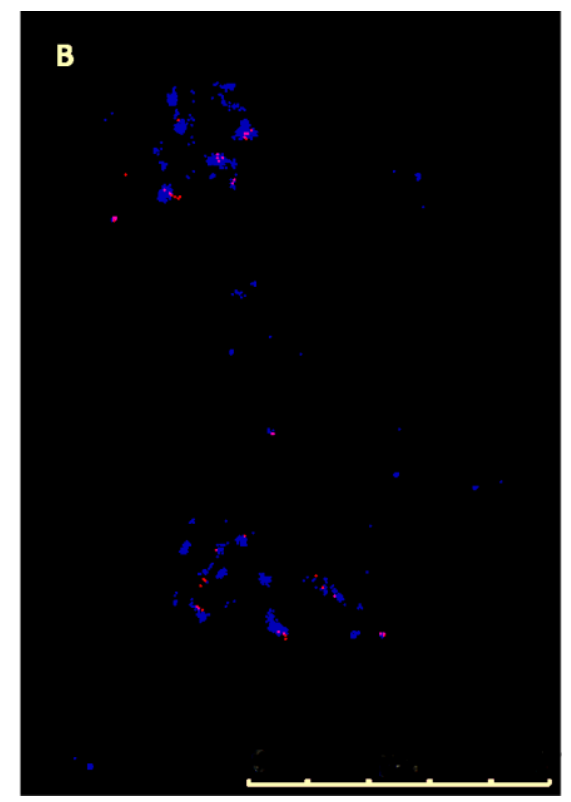

Fig. 1. Display of SIRE1 ENV distributions in barley root preparations via FISH. According to FISH results, characteristic feature of SIRE1 ENVs are localized in centred regions. Scale bar=7.5 and $25 \mu \mathrm{m}$ for A and B, respectively. 


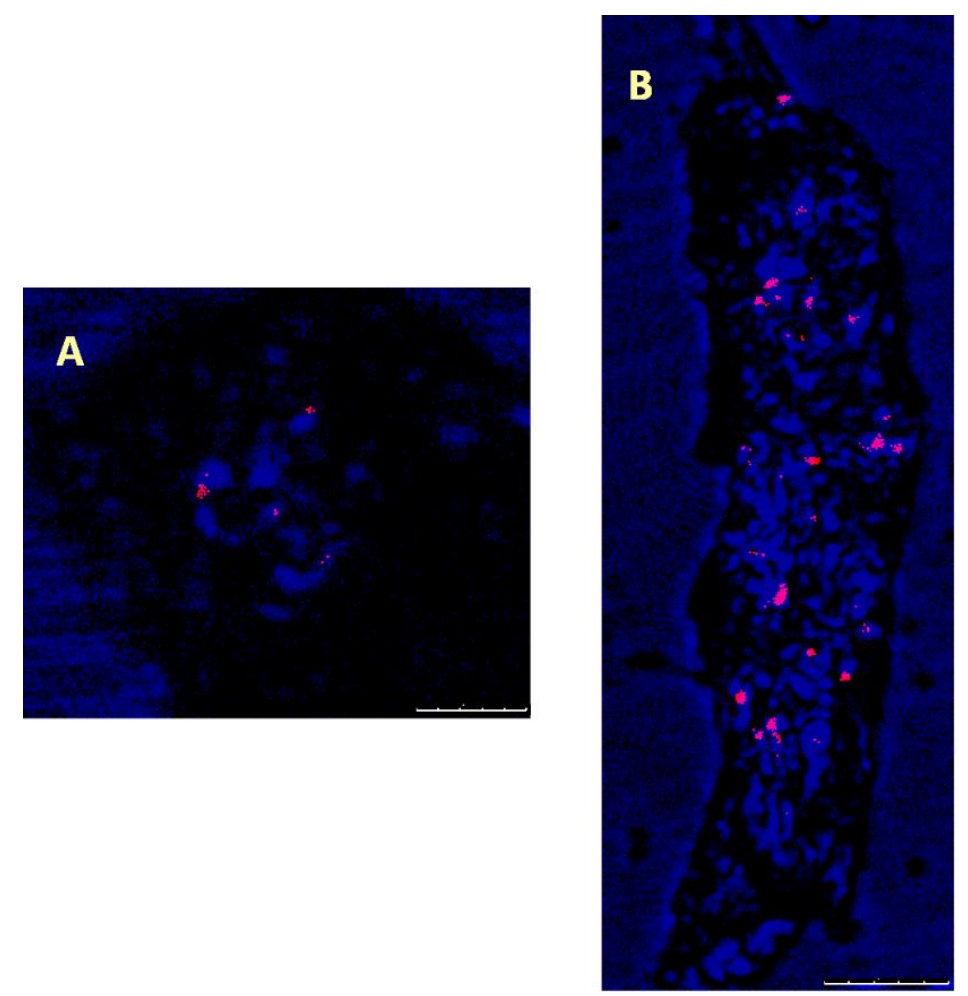

Fig. 2. Demonstrations of SIRE1 GAG localizations in barley root preparations via FISH. According to FISH results, SIRE GAGs are distinctively localized close to centred regions, similarly SIRE1 ENV. Scale bar=5 and $10 \mu \mathrm{m}$ for A and B, respectively.

\section{Discussion}

In plants, retroelements cover a large zone of genomes and are considered to have participated in the genome organization and evolution (McCarthy et al. 2002). Several studies have focused to detecting the chromosomal position of Tyl-copia retroelements, including SIRE1 and anticipating their copy number (Pearce et al. 1996, Lin et al. 2005, Alipour et al. 2013, Kolano et al. 2013, Lee et al. 2013). In the current study, localizations of SIRE1 ENV and GAG domains were indicated on barley chromosomes (see Fig. 1 and 2). The results were obtained from Hordeum vulgare L. cv. Hasat root tips preparations using FISH analysis. Due to the large genome size of barley, researchers mostly prefer to use single-copy probes derived from BAC or YAC contigs (Vicient et al. 1999, Acevedo-Garcia et al. 2013, Bustamante et al. 2017). In our study, we used direct PCR products derived from barley DNA to produce singlestranded probes were small, appx. 233 bp for $E N V$ and 120 bp for $G A G$. These small PCR probes were highly specific and stable for hybridization thus, it leads to very good amplification of the signals. By using short size of probes, we were able to visualize the first time SIRE1 ENV and $G A G$ distribution patterns on barley chromosomes, indicating they intend to demonstrate different patterns. Additionally, it is possible to observe localization of lncRNAs on chromosomes and in the cells using direct labelled-PCR products via FISH techniques (Karlik et al. 2018).

In plant genomes, most of the TEs are amplified to thousands of copies and present as low- or moderate- number copies (Baucom et al. 2009). Besides increasing genome sizes, TEs can impact on genome structure and gene expression at a global scale. Moreover, deletions of the interleaving genome sequences or creations of new chromosomal rearrangements can be generated by recombination between two TEs (Weil \& Wessle 1993, Hughes et al. 2003, Vicient \& Casacuberta 2017). However, TE karyotype differences may be significant tool contributing to reproductive isolations of TEs and crop domestication, to discriminate species diversification in plants (Vicient \& Casacuberta 2017). Also, the abundance and size of LTR retrotransposons in plant genomes exert interesting questions on how they affect genes and how they are regulated so that their insertions do not negatively influence the host genome (GalindoGonzález et al. 2017). Mascher et al. (2017) identified 3.7 $\mathrm{Gb}(80.8 \%)$ of the assembled barley genome sequence as derived from TEs, most of them were present as truncated and degenerated copies. Interestingly, only $10 \%$ of mobile elements are intact and potentially active. According to the sequencing results of Mascher et al. (2017), TEs presented notable variation in their insertion site preferences. The distribution of SIRE1 ENV and GAG barley were consistent with each other that they were mostly characterized close to the centromere regions (see Fig. 1 and 2). Presting et al. (1998) demonstrated the centromere of barley is enriched with cereba is a member of the Ty3/Gypsy class, that 200 copies of cereba have been determined in each barley centromere (Hudakova et al. 2001, Houben \& Schubert 2003). Two conserved centromere-specific repeats [Cereal Centromeric Sequence1 (CCS1) and Sau3A9] were reported, later is 
revealed that they are related to Ty3/Gypsy-like retrotransposons. In barley, parts of the LTRs of cereba element and parts of integrase region of its polygene correspond to CCS1 and Sau3A9, respectively (Hudakova et al. 2001). Our results also indicated that presence of SIRE1 is favoured mostly in regions close to centre locations that as we know SIRE1 is active and belongs to the Tyl/Copia retrotransposon superfamily (Lin et al. 2005). However, SIRE1 may be related to the centromeric repeats BCS1/CCS1 (barley cereal centromeric sequence), thus these elements may also contribute to SIRE1 elements movements. Lin et al. (2005) reported the presence of a 102-bp tandem repeat (STR102) which was a SIRE1 element and a SIRE1 solo LTR in soybean. However, the flanking sequences of 3 of 10 SIRE1 insertions were found to be repetitive, belonging to either Ty3/gypsy or other repetitive families (Laten et al. 1998). Moreover, these fragments have been demonstrated for maize and rice (Ananiev et al. 1998, Cheng et al. 2002) suggesting that they are common motifs of higher plants of centromeric/pericentromeric regions (MartinezZapater et al. 1986, Ananiev et al. 1998, Cheng et al. 2002, Lin et al. 2005), which is also consistent with our results. In soybean, Lin et al. (2005) also considered that SIRE1 may preferentially get in heterochromatic and/or pericentromeric regions which may alternatively be selected against the gene-rich euchromatic regions. In barley, we also observed that SIRE1 elements were mostly

\section{References}

1. Acevedo-Garcia, J., Collins, N.C., Ahmadinejad, N., Ma, L., Houben, A., Bednarek, P., Benjdia, M., Freialdenhoven, A., Altmüller, J., Nürnberg, P., Reinhardt, R., SchulzeLefert, P. \& Panstruga, R. 2013. Fine mapping and chromosome walking towards the Rorl locus in barley (Hordeum vulgare L.). Theoretical and Applied Genetics, 126(12): 2969-2982. https://doi.org/10.1007/s00122-013$\underline{\text { 2186-6 }}$

2. Alipour, A., Tsuchimoto, S., Sakai, H., Ohmido, N. \& Fukui, K. 2013. Structural characterization of copia-type retrotransposons leads to insights into the marker development in a biofuel crop, L Jatropha curcas. Biotechnology for Biofuel, 6(1): 129. https://doi.org/10.1186/1754-6834-6-129

3. Ananiev, E.V., Phillips, R.L. \& Rines, H.W. 1998. Chromosome-specific molecular organization of maize (Zea mays L.) centromeric regions. Proceedings of the National Academy of Sciences of the USA, 95 (22): 1307313078. https://doi.org/10.1073/pnas.95.22.13073

4. Baucom, R.S., Estill, J.C., Chaparro, C., Upshaw, N., Jogi, A., Deragon, J.M., Westerman, R.P., Sanmiguel, P.J. \& Bennetzen, J.L. 2009. Exceptional diversity, non-random distribution, and rapid evolution of retroelements in the B73 maize genome. PLoS Genetics, 5(11): e1000732. https://doi.org/10.1371/journal.pgen.1000732

5. Bousios, A., Darzentas, N., Tsaftaris, A. \& Pearce, S.R. 2010. Highly conserved motifs in noncoding regions of Sirevirus retrotransposons: the key for their pattern of concentrated in centred regions. FISH analysis of barley SIRE1 elements provided us to allow cursory insight into the barley genome organization.

In conclusion, we were able to observe the distinctive distributions of the SIRE1 ENV and GAG elements via FISH analysis by using labelled-PCR products as probes in barley root preparations. How these elements function to organize genome is still a mystery, however the applications of FISH analysis of TEs may have an important potential to uncover the organization of higher plant genomes.

\section{Acknowledgement}

The authors thank Dr. Stuart James Lucas for his kind revision.

Author Contributions: Execution: E.K., Material supplying: E.K., Manuscript writing: E.K., Critical revision: N.G.

Ethics Committee Approval: Since the article does not contain any studies with human or animal subject, its approval to the ethics committee was not required.

Conflict of Interest: The authors have no conflicts of interest to declare.

Funding: The author declared that this study has received no financial support.

distribution within and across plants?. BMC Genomics, 11: 89. https://doi.org/10.1186/1471-2164-11-89

6. Bustamante, F.O., Aliyeva-Schnorr, L., Fuchs, J., Beier, S. \& Houben, A. 2017. Correlating the genetic and physical map of barley chromosome $3 \mathrm{H}$ revealed limitations of the FISH-based mapping of nearby single-copy probes caused by the dynamic structure of metaphase chromosomes. Cytogenetic and Genome Research, 152(2): 90-96. https://doi.org/10.1159/000478631

7. Cheng, Z., Dong, F., Langdon, T., Ouyang, S., Buell, C.R., Gu, M., Blattner, F.R. \& Jiang, J. 2002. Functional rice centromeres are marked by a satellite repeat and a centromere-specific retrotransposon. Plant Cell, 14(8): 1691-1704. https://doi.org/10.1105/tpc.003079

8. Friesen N., Brandes, A. \& Heslop-Harrison, J. 2001. Diversity, origin and distribution of retrotransposons in conifers. Molecular Biology and Evolution, 18(7): 11761188.

https://doi.org/10.1093/oxfordjournals.molbev.a003905.

9. Galindo-González, L., Mhiri, C., Deyholos, M.K. \& Grandbastien, M.A. 2017. LTR-retrotransposons in plants: engines of evolution. Gene, 626: 14-25. https://doi.org/10.1016/j.gene.2017.04.051

10. Gao, X., Havecker, E.R., Baranov, P.V., Atkins, J.F. \& Voytas, D.F. 2003. Translational recoding signals between gag and pol in diverse LTR retrotransposons. RNA, 9(12): 1422-1430. https://doi.org/10.1261/rna.5105503 
11. Hausmann, M. \& Cremer, C. 2003. Standardization of FISH-procedures: Summary of the first discussion workshop. Analytical Cellular Pathology, 25(4): 201-205. https://doi.org/10.1155/2003/427509

12. Havecker, E.R., Gao, X. \& Voytas, D.F. 2005. The sireviruses, a plant-specific lineage of the Tyl/copia retrotransposons, interact with a family of proteins related to dynein light chain. Plant Physiology, 139(2): 857-868. https://doi.org/10.1104/pp.105.065680

13. Houben, A. \& Schubert, I. 2003. DNA and proteins of plant centromeres. Current Opinion in Plant Biology, 6(6): 554560. https://doi.org/10.1016/j.pbi.2003.09.007

14. Hudakova, S., Michalek, W., Presting, G.G., Ten Hoopen, R., Dos Santos, K., Jasencakova, Z. \& Schubert, I. 2001. Sequence organization of barley centromeres. Nucleic Acids Research, 29(24): 5029-5035. https://doi.org/10.1093/nar/29.24.5029

15. Hughes, A.L., Friedman, R., Ekollu, V. \& Rose, J.R. 2003. Non-random association of transposable elements with duplicated genomic blocks in Arabidopsis thaliana. Molecular Phylogenetics and Evolution, 29(3): 410-416. https://doi.org/10.1016/S1055-7903(03)00262-8

16. Jenkins, G. \& Hasterok, R. 2001. Painting whole chromosome sets in hybrids using GISH, in Advanced Molecular Cytogenetics - a practical course manual. Wydawnictwo Uniwersytetu Śląskiego. 35-48.

17. Jenkins, G. \& Hasterok, R. 2007. BAC 'landing' on chromosomes of Brachypodium distachyon for comparative genome alignment. Nature Protocols, 2: 8898. https://doi.org/10.1038/nprot.2006.490

18. Karlik, E., Marakli, S. \& Gozukirmizi, N. 2018. Two lncRNAs expression profiles in salt stressed barley (Hordeum vulgare L.) roots. Cytologia, 83(1): 37-43. https://doi.org/10.1508/cytologia.83.37

19. Kiseleva, A.V., Kirov, I.V. \& Khrustaleva, L.I. 2014. Chromosomal organization of centromeric Ty3/gypsy retrotransposons in Allium cepa $\mathrm{L}$. and Allium fistulosum L. Russian Journal of Genetics, 50(6): 670-676. https://doi.org/10.1134/S102279541404005X

20. Kolano, B., Bednara, E. \& Weiss-Schneeweiss, H. 2013. Isolation and characterization of reverse transcriptase fragments of LTR retrotransposons from the genome of Chenopodium quinoa (Amaranthaceae). Plant Cell Reports, $\quad 32(10)$ : 1575-1588. https://doi.org/10.1007/s00299-013-1468-4

21. Kumar, A. \& Bennetzen, J.L. 1999. Plant retrotransposons. Annual Review of Genetics, 33: 479-532. https://doi.org/10.1146/annurev.genet.33.1.479

22. Laten, H.M., Majumdar, A. \& Gaucher, E.A. 1998. SIRE1, a copia/Ty1-like retroelement from soybean, encodes a retroviral envelope-like protein. Proceedings of the National Academy of Sciences of the USA, 95(12): 68976902. https://doi.org/10.1073/pnas.95.12.6897

23. Lee, S.I., Park, K.C., Son, J.H., Hwang, Y.J., Lim, K.B., Song, Y.S., Kim, J.H. \& Kim, N.S. 2013. Isolation and characterization of novel Tyl-copia-like retrotransposons from lily. Genome, 56(9): 495-503. https://doi.org/10.1139/gen-2013-0088
24. Li, Y., Zuo, S., Zhang, Z., Li, Z., Han, J., Chu, Z., Hasterok, R. \& Wang, K. 2018. Centromeric DNA characterization in the model grass Brachypodium distachyon provides insights on the evolution of the genus. The Plant Journal, 93(6): 1088-1101. https://doi.org/10.1111/tpj.13832

25. Lin, J.Y., Jacobus, B.H., Sanmiguel, P., Walling, J.G., Yuan, Y., Shoemaker, R.C., Young, N.D. \& Jackson, S.A. 2005. Pericentromeric regions of soybean (Glycine max L. Merr.) chromosomes consist of retroelements and tandemly repeated DNA and are structurally and evolutionarily labile. Genetics, 170(3): 1221-1230. https://doi.org/10.1534/genetics.105.041616

26. Llorens, C., Munoz-Pomer, A., Bernard, L., Botella, H. \& Moya, A. 2009. Network dynamics of eukaryotic LTR retroelements beyond phylogenetic trees. Biology Direct, 4(41). https://doi.org/10.1186/1745-6150-4-41

27. Mafra, I., Silva, S.A., Moreira, E.J.M.O., Ferreira Da Silva, C.S., Beatriz, M. \& Oliveira, P.P. 2008. Comparative study of DNA extraction methods for soybean derived food products. Food Control, 19(12): 1183-1190. https://doi.org/10.1016/j.foodcont.2008.01.004

28. Martinez-Zapater, J.M., Estelle, M.A. \& Somerville, C.R. 1986. A highly repeated DNA sequence in Arabidopsis thaliana. Molecular and General Genetics, 204(3): 417423. https://doi.org/10.1007/BF00331018

29. Mascher, M., Gundlach, H., Himmelbach, A., Beier, S., Twardziok, S. O., Wicker, T., Radchuk, V., Dockter, C., Hedley, P. E., Russell, J., Bayer, M., Ramsay, L., Liu, H., Haberer, G., Zhang, X. Q., Zhang, Q., Barrero, R. A., Li, L., Taudien, S., Groth, M., Felder, M., Hastie, A., Šimková, H., Staňková, H., Vrána, J., Chan, S., Muñoz-Amatriaín, M., Ounit, R., Wanamaker, S., Bolser, D., Colmsee, C., Schmutzer, T., Aliyeva-Schnorr, L., Grasso, S., Tanskanen, J., Chailyan, A., Sampath, D., Heavens, D., Clissold, L., Cao, S., Chapman, B., Dai, F., Han, Y., Li, H., Li, X., Lin, C., McCooke, J. K., Tan, C., Wang, P., Wang, S., Yin, S., Zhou, G., Poland, J. A., Bellgard, M. I., Borisjuk, L., Houben, A., Doležel, J., Ayling, S., Lonardi, S., Kersey, P., Langridge, P., Muehlbauer, G. J., Clark, M. D., Caccamo, M., Schulman, A. H., Mayer, K. F. X., Platzer, M., Close, T. J., Scholz, U., Hansson, M., Zhang, G., Braumann, I., Spannagl, M., Li, C., Waugh, R. and Stein, N. 2017. A chromosome conformation capture ordered sequence of the barley genome. Nature, 26: 427-433. https://doi.org/10.1038/nature22043

30. Mccarthy, E.M., Liu, J., Lizhi, G. \& Mcdonald, J.F. 2002. Long terminal repeat retrotransposons of Oryza sativa. Genome Biology, 3(10): 1-11. https://doi.org/10.1186/gb2002-3-10-research0053

31. Pearce, S.R., Pich, U., Harrison, G., Flavell, A.J., HeslopHarrison, J.S., Schubert, I. \& Kumar, A. 1996. The Tylcopia group retrotransposons of Allium cepa are distributed throughout the chromosomes but are enriched in the terminal heterochromatin. Chromosome Research, 4(5): 357-364. https://doi.org/10.1007/BF02257271

32. Peterson-Burch, B.D. \& Voytas, D.F. 2002. Genes of the Pseudoviridae (Ty1/copia retrotransposons). Molecular Biology and Evolution, 19(11): 18321845. https://doi.org/10.1093/oxfordjournals.molbev.a004 $\underline{008}$ 
33. Presting, G.G., Malysheva, L., Fuchs, J. \& Schubert, I. 1998. A Ty3/gypsy retrotransposon-like sequence localizes to the centromeric regions of cereal chromosomes. The Plant Journal, 16(6): 721-728. https://doi.org/10.1046/j.1365-313x.1998.00341.x

34. Salvo-Garrido, H.G., Travella, S., Schwarzacher, T., Harwood, W.A. \& Snape, J.W. 2001. An efficient method for the physical mapping of transgenes in barley using in situ hybridization. Genome, $\quad 44(1)$ : 104-110. https://doi.org/10.1139/gen-44-1-104

35. Sandmeyer, S.B., Aye, M. \& Menees, T. 2002. Ty3, a position-specific, gypsy-like element in Saccharomyces cerevisiae. In: Mobile DNA II, Craig, N.L., Craigie, R., Gellert, M., Lambowitz, A.M. (eds.). Washington DC: ASM Press. 663-683.

36. Schnable, P.S., Ware, D., Fulton, R. S., Stein, J. C., Wei, F., Pasternak, S., Liang, C., Zhang, J., Fulton, L., Graves, T.A., Minx, P., Reily, A.D., Courtney, L., Kruchowski, S. S., Tomlinson, C., Strong, C., Delehaunty, K., Fronick, C., Courtney, B., Rock, S. M., Belter, E., Du, F., Kim, K., Abbott, R. M., Cotton, M., Levy, A., Marchetto, P., Ochoa, K., Jackson, S. M., Gillam, B., Chen, W., Yan, L., Higginbotham, J., Cardenas, M., Waligorski, J., Applebaum, E., Phelps, L., Falcone, J., Kanchi, K., Thane, T., Scimone, A., Thane, N., Henke, J., Wang, T., Ruppert, J., Shah, N., Rotter, K., Hodges, J., Ingenthron, E., Cordes, M., Kohlberg, S., Sgro, J., Delgado, B., Mead, K., Chinwalla, A., Leonard, S., Crouse, K., Collura, K., Kudrna, D., Currie, J., He, R., Angelova, A., Rajasekar, S., Mueller, T., Lomeli, R., Scara, G., Ko, A., Delaney, K., Wissotski, M., Lopez, G., Campos, D., Braidotti, M., Ashley, E., Golser, W., Kim, H., Lee, S., Lin, J., Dujmic, Z., Kim, W., Talag, J., Zuccolo, A., Fan, C., Sebastian, A., Kramer, M., Spiegel, L., Nascimento, L., Zutavern, T., Miller, B., Ambroise, C., Muller, S., Spooner, W., Narechania, A., Ren, L., Wei, S., Kumari, S., Faga, B., Levy, M. J., McMahan, L., Van Buren, P. \& Vaughn, M.W. (2009). The B73 maize genome: Complexity, diversity, and dynamics. Science, 326(5956), 1112-1115. https://doi.org/10.1126/science.1178534
37. Schulman, A.H. \& Wicker, T. 2013. A field guide to transposable elements, In: Plant Transposons and Genome Dynamics in Evolution, Fedoroff, N.V. (ed.). Oxford: Wiley Blackwell. 15-40.

38. Shams, I. \& Raskina, O. 2018. Intraspecific and intraorganismal copy number dynamics of retrotransposons and tandem repeat in Aegilops speltoides Tausch (Poaceae, Triticeae). Protoplasma, $255(4): \quad$ 1023-1038. https://doi.org/10.1007/s00709-018-1212-6

39. The Arabidopsis Genome Initiative. 2000. Analysis of the genome sequence of the flowering plant Arabidopsis thaliana. $\quad$ Nature, 408: 796-815. https://doi.org/10.1038/35048692

40. Vicient, C.M., Kalendar, R., Anamthawat-Jansson, K. \& Schulman, A.H. 1999. Structure, functionality, and evolution of the BARE-1 retrotransposon of barley. Genetica, $\quad 107(1-3)$ : 53-63. https://doi.org/10.1023/A:1003929913398

41. Vicient, C.M. \& Casacuberta, J.M. 2017. Impact of transposable elements on polyploid plant genomes. Annals of Botany, 120(2): 195-207. https://doi.org/10.1093/aob/mcx078

42. Voytas, D.F. \& Boeke, J.D. 2002. Ty1 and Ty5 of Saccharomyces cereviceae, In: Mobile DNA II, Craig, N.L., Craigie, R., Gellert, M. \& Lambowitz, A.M. (eds.). Washington DC: ASM Press. 631-662.

43. Wicker, T., Sabot, F., Hua-Van, A., Bennetzen, J., Capy, P., Chalhoub, B., Flavell, A.J., Leroy, P., Morgante, M., Panaud, O., Paux, E., Sanmiguel, P. \& Schulman, A.H. 2007. A unified classification system for eukaryotic transposable elements. Nature Reviews Genetics, 8(12): 973-982. https://doi.org/10.1038/nrg2165

44. Weil, C.F. \& Wessler, S.R. 1993. Molecular evidence that chromosome breakage by $D s$ elements is caused by aberrant transposition. Plant Cell, 5(5): 515-522. https://doi.org/10.1105/tpc.5.5.515 